\title{
A Short Olefin Metathesis-Based Route to Enantiomerically Pure Arylated Dihydropyrans and $\alpha_{\boldsymbol{}} \beta$-Unsaturated $\delta$-Valero Lactones
}

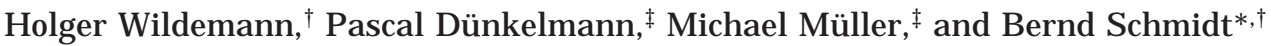 \\ FB Chemie der Universität Dortmund, Organische Chemie, D-44221 Dortmund, Germany, and \\ Institut für Biotechnologie 2, Forschungszentrum J ülich GmbH, D-52425 J ülich, Germany
}

bschmidt@chemieuni-dortmund.de

Received September 25, 2002

\begin{abstract}
The synthesis of arylated dihydropyrans and unsaturated lactones starting from enantiomerically pure $\alpha$-hydroxy ketones (prepared by an enzyme-catalyzed benzoin condensation) is described. The key steps are a highly diastereoselective addition of vinyl metal compounds under chelate control and a ruthenium-catalyzed ring-closing ol efin metathesis reaction. Elucidation of the relative configuration of the final products was achieved by NOE experiments.
\end{abstract}

Arylated heterocycles have been a synthetic target in several pharmaceutical research laboratories. Potential applications range from 5-Lipoxygenase inhibitors ${ }^{1}$ to NK-1 receptor antagonists 2,3 and ligands for receptors of neurotransmitters. 4,5 Methods for the introduction of aryl moieties to heterocycles include Heck reactions ${ }^{2}$ or Stille couplings, ${ }^{3}$ asymmetric Michael reactions of aryl acetic acids, ${ }^{6}$ and addition of aryl metal compounds to heterocycloalkanones. Two examples of biologically active heterocycles synthesized by this method are depicted in Figure 1: the piperidine $\mathbf{1}$ shows adrenoceptor agonist activity, ${ }^{7}$ while the tetrahydropyran $\mathbf{2}$ inhibits leukotriene synthesis in vitro. ${ }^{1}$

The structural pattern present in $\mathbf{2}$ inspired a short and highly diastereoselective synthesis of more densely functionalized enantiomerically pure analogues. Our synthetic concept is based on the ring-closing olefin metathesis reaction ${ }^{8-11}$ and uses enantiomerically pure $\alpha$-hydroxy-aryl ketones $\mathbf{3}$ as starting materials. The ketones $\mathbf{3}$ were obtained on a preparative scale in high

\footnotetext{
${ }^{\dagger}$ FB Chemie der Universität Dortmund.
}

₹ Institut für Biotechnologie 2 .

(1) Crawley, G. C.; Dowell, R. I.; Edwards, P. N.; Foster, S. J .; McMillan, R. M.; Walker, E. R. H.; Waterson, D. J . Med. Chem. 1992, 35, 2600-2609.

(2) Kulagowski, J .J .; Curtis, N. R.; Swain, C. J .; Williams, B. J . Org. Lett. 2001, 3, 667-670.

(3) Wallace, D. J .; Goodman, J . M.; Kennedy, D. J .; Davies, A. J .; Cowden, C. J .; Ashwood, M. S.; Cottrell, I. F.; Dolling, U.-H.; Reider, P. J . Org. Lett. 2001, 3, 671-674.

(4) Petukhov, P. A.; Zhang, J. R.; Kozikowski, A. P.; Wang, C. Z.; Ye, Y. P.; J ohnson, K. M.; Tella, S. R. J . Med. Chem. 2002, 45, 31613170.

(5) Amat, M.; Cantó, M.; Llor, N.; Escolano, C.; Molins, E.; Espinosa, E.; Bosch, J.J . Org. Chem. 2002, 67, 5343-5351.

(6) Smitrovich, J. H.; Boice, G. N.; Qu, C.; DiMichele, L.; Nelson, T. D.; Huffman, M. A.; Murry, J .; McNamara, J .; Reider, P. J . Org. Lett. 2002, 4, 1963-1966.

(7) Macchia, B.; Balsamo, A.; Epifani, E.; Lapucci, A.; Nencetti, S.; Macchia, F.; Breschi, M. C.; Martinotti, E.; Ceserani, R. J . Med. Chem. 1986, 29, 740-747.

(8) Armstrong, S. K. J . Chem. Soc., Perkin Trans. 1 1998, 371-388.

(9) Grubbs, R. H.; Chang, S. Tetrahedron 1998, 54, 4413-4450.

(10) Schuster, M.; Blechert, S. Angew. Chem., Int. Ed. Engl. 1997, 36, 2036-2055.

(11) Fürstner, A. Angew. Chem., Int. Ed. 2000, 39, 3013-3043.

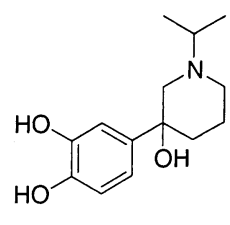

1

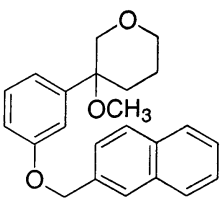

2
FIGURE 1. Examples for biologically active, arylated heterocycles.

chemical and optical yield by benzaldehyde lyase (BAL)catalyzed benzoin condensation-like reaction from aromatic aldehydes and acetaldehyde. ${ }^{12,13}$ U sing this thiamine diphosphate (ThDP)-dependent enzyme in an aqueous buffer solution a large number of highly enantioenriched ( $R$ )-benzoins and (R)-2-hydroxy-1-phenyl-1-propanones substituted in ortho-, meta-, and para-positions by diverse moieties are available in one reaction step. Additionally, direct access to the corresponding (S)enantiomers is also given by using the same enzymes' racemic resolution ability or by using other ThDPdependent enzymes. ${ }^{14,15}$

Following the sequence outlined in Scheme 1, dihydropyrans $\mathbf{7 a}-\mathbf{e}$ were obtained as single diastereomers in enantiomerically pure form.

Starting from $\alpha$-hydroxy ketones 3, allyloxy ketones $\mathbf{4}$ were obtained using silver oxide and allyl bromide. ${ }^{16}$ By using this method, racemization at the $\alpha$-carbon was avoided and allyl ethers $\mathbf{4}$ were obtained in an enantio-

(12) Demir, A. S.; Pohl, M.; J anzen, E.; Müller, M. J . Chem. Soc., Perkin Trans. 1 2001, 633-635.

(13) Demir, A. S.; Sesenoglu, Ö.; Eren, E.; Hosrik, B.; Pohl, M.; J anzen, E.; Kolter, D.; Feldmann, R.; Dünkelmann, P.; Müller, M. Adv. Synth. Catal. 2002, 344, 96-103.

(14) Demir, A. S.; Dünnwald, T.; I ding, H.; Pohl, M.; Müller, M. Tetrahedron: Asymmetry 1999, 10, 4769-4774.

(15) Iding, H.; Dünnwald, T.; Greiner, L.; Liese, A.; Müller, M.; Siegert, P.; Grötzinger, J .; Demir, A. S.; Pohl, M. Chem. Eur. J . 2000 6, 1483-1495.

(16) Aurich, H. G.; Biesemeier, F.; Boutahar, M. Chem. Ber. 1991 $124,2329-2334$ 


\section{SCHEME $\mathbf{P}$}

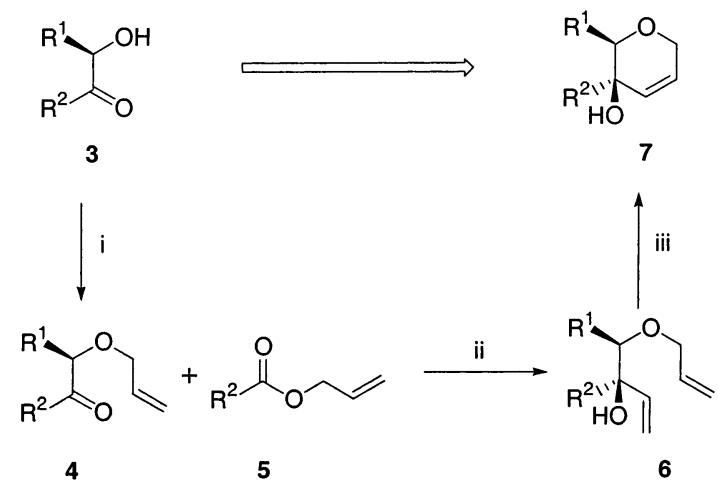

a Reagents and conditions: (i) $\mathrm{Ag}_{2} \mathrm{O}$ (1.5 equiv), $\mathrm{H}_{2} \mathrm{C}=\mathrm{CHCH}_{2} \mathrm{Br}$, ether, $20^{\circ} \mathrm{C}$; (ii) $\mathrm{H}_{2} \mathrm{C}=\mathrm{CHMgCl}$, ether, $-78^{\circ} \mathrm{C}$; (iii) $\mathrm{Cl}_{2}\left(\mathrm{Cy}_{3} \mathrm{P}\right)_{2} \mathrm{Ru}=\mathrm{CHPh}$ (A) (3 mol \%), $\mathrm{CH}_{2} \mathrm{Cl}_{2}, 20^{\circ} \mathrm{C}$.

TABLE 1. Synthesis of Arylated Dihydropyrans

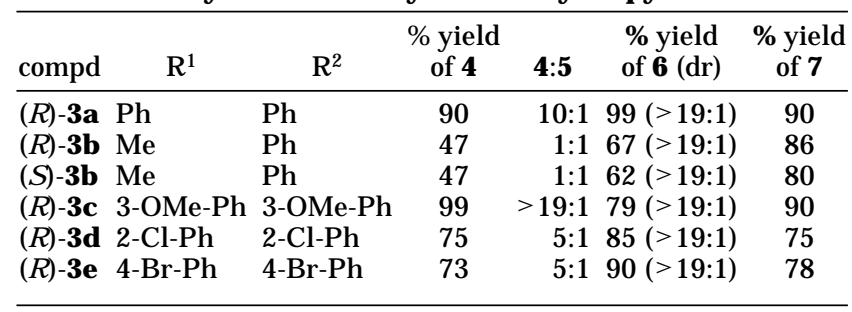

merically pure form. If strong bases, such as $\mathrm{NaH}$, are used, an O-allylation-Wittig rearrangement takes place, leading to aryl-allyl carbinols. ${ }^{17}$ In the case of (R)- and (S)-3b, allyl benzoate was formed as an inseparable byproduct. Obviously, oxidative cleavage of the acyloin linkage occurs, leading to benzoic acid, which is then allylated to give the corresponding allyl ester. In all other cases, only minor amounts of allyl esters $\mathbf{5}$ result. The amount of $\mathbf{5}$ increases with an increasing amount of silver oxide, thus, a large excess of silver oxide should be carefully avoided. By treatment of the $\alpha$-allyloxy ketones 4 with vinylmagnesium chloride in THF/ether at low temperature, the dienes $\mathbf{6}$ were obtained with very high diastereoselectivity. In all cases investigated, only one diastereomer could be detected in the proton NMR spectrum of the crude reaction mixture, corresponding to a diastereomeric ratio higher than 19:1. For 6a we proved that the vinylation reaction occurs without any racemization. Racemic $\mathbf{6 a}$ was prepared from commercial benzoin and compared with material obtained via the same sequence from (R)-3a using HPLC on chirally modified stationary phases. The amount of the S-enantiomer was below the detection limit corresponding to an enanantiomeric excess of $>99 \%$. Ring-cl osing metathesis of the dienes 6 to the dihydropyrans 7 proceeded smoothly in the presence of $3 \mathrm{~mol} \%$ of the first generation Grubbs' catalyst (A in Figure 2). Only $\mathbf{6 d}$ required $10 \mathrm{~mol} \%$ of the ruthenium catalyst for complete conversion to the di hydropyran $\mathbf{7 d}$. The significantly reduced reactivity of 6d might be explained by steric interactions of the substituent in the ortho-position of the aromatic ring with the ligand sphere of the ruthenium complex. As a consequence, conformations suitable for ring closure

(17) Schmidt, B.; Wildemann, H. J . Chem. Soc., Perkin Trans. 1 2000, 2916-2925.

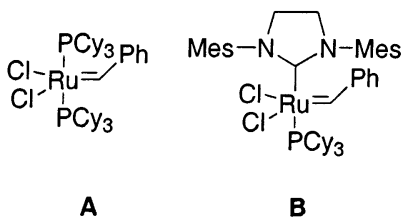

FIGURE 2. First (A) and second (B) generation Grubbs' catalyst.

become higher in energy compared to derivatives not substituted in the ortho-position.

Modification of the sequence outlined above allows the conversi on of $\alpha$-hydroxy ketones to $\alpha, \beta$-unsaturated lactones 10. Starting from $\mathbf{3 c}, \mathbf{f}$, vinylation to the corresponding diol $\mathbf{8 c}$, $\mathbf{f}$ is achieved by addition of excess vinylmagnesium chloride. Again, HPLC on chirally modified stationary phases proved that no racemization occurs on this step. For this purpose, racemic $\mathbf{8 c}$ was prepared from the corresponding racemic benzoin and compared with material obtained from enantiomerically pure (R)3c. In this case a small amount of the S-enantiomer was observed (ee of (R)-8c: 98\%). The diols 8c,f were converted to the acrylates $\mathbf{9 c}, \mathbf{f}$ by reaction with acryloyl chloride. Competitive esterification of the tertiary alcohol was not observed if a large excess of base and acryloyl chloride was avoided and if the reaction was quenched immediately after consumption of the starting material ( $T L C$ control). Conversion of the sterically more hindered substrate $8 \mathrm{c}$ to $9 \mathrm{c}$ requires longer reaction times and the addition of a catalytic amount of DMAP. \&f is readily converted to $9 f$ without additives.

Ring-closing metathesis of dienes containing one electron-deficient double bond with the first generation catalyst $\mathbf{A}$ is normally not a facile process due to the inhibition of the catalytically active species by chelation. This problem may be circumvented by addition of a Lewis acid, ${ }^{18}$ or by using the second generation catalyst B. ${ }^{19} \mathrm{We}$ chose the latter option for converting dienes $\mathbf{9 c}, \mathbf{f}$ to the corresponding lactones $\mathbf{1 0 c}, \mathbf{f}$. In the presence of $4 \mathrm{~mol} \%$ of $\mathbf{B}$ complete conversion was achieved within $30 \mathrm{~min}$ at $70{ }^{\circ} \mathrm{C}$. Over the past three years some examples of the formation of $\alpha, \beta$-unsaturated lactones by ol efin metathesis of acrylates using complex $\mathbf{B}$ have been described in the literature. ${ }^{20-23}$ Nevertheless, it is surprising that ring closure of the sterically demanding and electron-deficient dienes 9 is such a smooth process. The results are summarized in Scheme 2 and Table 2.

The relative stereochemistry was investigated for the cyclic products by NOE experiments. Gradient-sel ected one-dimensional NOE experiments were conducted at $600 \mathrm{MHz}$ for the dihydropyrans $\mathbf{7 a}, \mathbf{b}, \mathbf{e}$ and the lactone 10f. F or the dihydropyrans a NOE interaction of $\mathrm{H} 2$ with one of the protons $\mathrm{H} 6$ is indicative of a pseudoaxial

(18) Fürstner, A.; Langemann, K. Synthesis 1997, 792-803.

(19) Scholl, M.; Trnka, T. M.; Morgan, J. P.; Grubbs, R. H. Tetrahedron Lett. 1999, 40, 2247-2250.

(20) Fürstner, A.; Thiel, O. R.; Kindler, N.; Bartkowska, B. J . Org. Chem. 2000, 65, 7990-7995.

(21) Held, C.; Fröhlich, R.; Metz, P. Angew. Chem., Int. Ed. 2001 40, 1058-1060.

(22) Fürstner, A.; Ackermann, L.; Gabor, B.; Goddard, R.; Lehmann, C. W.; Mynott, R.; Stelzer, F.; Thiel, O. R. Chem. Eur. J . 2001, 7, 32363253.

(23) Schmidt, B.; Pohler, M.; Costisella, B. Tetrahedron 2002, 58 $7951-7958$.

800 J. Org. Chem., Vol. 68, No. 3, 2003 


\section{SCHEME $2^{\mathrm{a}}$}

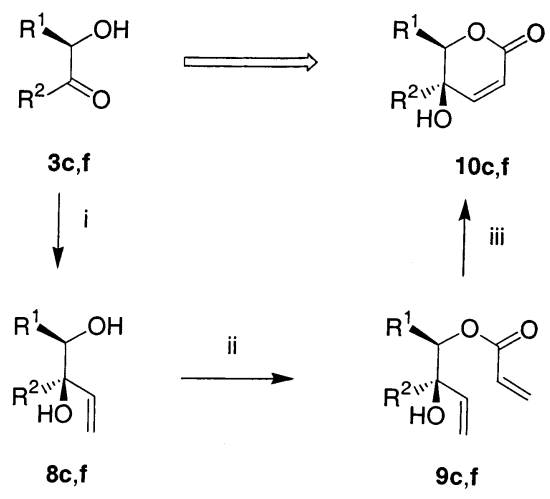

a Reagents and conditions: (i) $\mathrm{H}_{2} \mathrm{C}=\mathrm{CHMgCl}, \mathrm{THF},-78^{\circ} \mathrm{C}$; (ii) $\mathrm{H}_{2} \mathrm{C}=\mathrm{CHCOCl}, \mathrm{NEt}_{3}, \mathrm{DCM}$ (10 mol \% of DMAP for 9c); (iii) B (4 mol \%), toluene, $70^{\circ} \mathrm{C}$

TABLE 2. Synthesis of Arylated Lactones

\begin{tabular}{|c|c|c|c|c|c|}
\hline 3 & $\mathrm{R}^{1}$ & $\mathrm{R}^{2}$ & $\begin{array}{l}\text { \% yield } \\
\text { of } \mathbf{8}(\mathrm{dr})\end{array}$ & $\begin{array}{c}\text { \%yield } \\
\text { of } 9\end{array}$ & $\begin{array}{c}\text { \%yield } \\
\text { of } \mathbf{1 0}\end{array}$ \\
\hline $\begin{array}{l}\text { (R)-3c } \\
\text { (R)-3f }\end{array}$ & $\begin{array}{l}3-\mathrm{OCH}_{3}-\mathrm{Ph} \\
-\mathrm{CH}_{3}\end{array}$ & $\begin{array}{l}3-\mathrm{OCH}_{3}-\mathrm{Ph} \\
3-\mathrm{Cl}-\mathrm{Ph}\end{array}$ & $\begin{array}{l}76(17: 1) \\
81(>19: 1)\end{array}$ & $\begin{array}{l}80 \\
72\end{array}$ & $\begin{array}{l}95 \\
90\end{array}$ \\
\hline
\end{tabular}
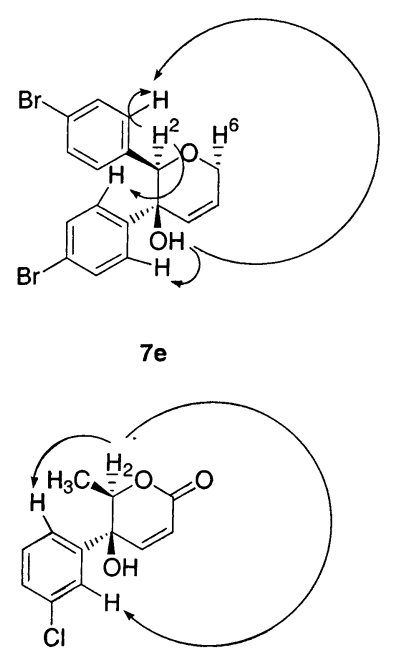

$10 f$

FIGURE 3. Representative NOE interactions in 7e and 10f.

orientation of these protons. $\mathrm{H} 2$ shows an NOE to the ortho-protons of the aromatic ring in the 3-position and to the substituent in the 2-position. However, no NOE interaction to the $\mathrm{OH}$ proton was observed. In contrast, the $\mathrm{OH}$ proton shows NOEs to both aromatic substituents and to the olefinic proton $\mathrm{H} 4$, but not to $\mathrm{H} 2$. From these observations we conclude that the substituents at $\mathrm{C} 2$ and C3 are trans-arranged. These NOE interactions are summarized for the example $7 e$ in Figure 3. For the lactone series, NOEs were recorded for 10f. Indicative NOE interactions are found between $\mathrm{H} 2$ and both ortho protons of the aryl moiety. NOE interactions between the methyl group in the 2-position and these ortho protons are significantly weaker (Figure 3 ).

The relative RS-stereochemistry of the al cohols $\mathbf{6}$ and 8 and the high degree of diastereoselectivity originates from a chelation effect first proposed by Cram ("Cram's

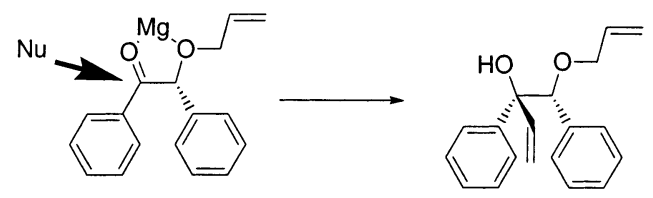

FIGURE 4. Rationalization of the stereochemical outcome in vinylation reactions.

cyclic model").24,25 The oxygen of the $\alpha$-allyloxy substituent or the hydroxy group and the carbonyl oxygen form a five-membered chelate complex, which is preferentially attacked from the sterically less shiel ded side, as outlined for the formation of $\mathbf{6 a}$ in Figure 4. The addition of organomagnesium compounds to $\alpha$-hydroxy ketones and factors governing the stereoselectivity of the addition step have al ready been thoroughly investigated. ${ }^{25,26}$

In conclusion, we have developed a highly diastereoselective route to enantiomerically pure dihydropyrans and $\alpha, \beta$-unsaturated lactones bearing one or two aromatic substituents. The synthetic concept is based on the use of $\alpha$-hydroxy ketones which are conveniently obtained in enantiomerically pure form, a highly diastereoselective vinylation relying on efficient chelate control, and a ringclosing ol efin metathesis step.

\section{Experimental Section}

General. All experiments were conducted in dry reaction vessels in an atmosphere of dry argon. Solvents were purified by standard procedures. ${ }^{1} \mathrm{H}$ NMR spectra were recorded at 400 or $500 \mathrm{MHz}$ in $\mathrm{CDCl}_{3}$ with $\mathrm{CHCl}_{3}(\delta 7.24 \mathrm{ppm})$ as internal standard. Coupling constants are given in hertz. ${ }^{13} \mathrm{C} \mathrm{NMR}$ spectra were recorded at 100 or $125 \mathrm{MHz}$ in $\mathrm{CDCl}_{3}$ with $\mathrm{CDCl}_{3}$ ( $\delta 77.0 \mathrm{ppm}$ ) as internal standard. The number of coupled protons was analyzed by DEPT or APT experiments and is denoted in parentheses following the $\delta_{C}$ values. Signal assignment for cyclic products follows a numbering scheme where the oxygen atom is numbered as 1 and the $\alpha$-carbon atom bearing the substituent $R^{1}$ (cf. Schemes 1 and 2) as C2. Selective 1D-NOE experiments were conducted using shaped pulses and pulsed field gradients at $600 \mathrm{MHz}$ with a mixing time of $800 \mathrm{~ms}$. IR spectra were recorded as films on $\mathrm{NaCl}$ or $\mathrm{KBr}$ plates or as $\mathrm{KBr}$ disks. The peak intensities are defined as strong (s), medium (m), and weak (w). Mass spectra were obtained at $70 \mathrm{eV}$. Optical purities were determined by HPLC using a HP-LC-1050 system equipped with a Daicel Chiralcel OD, a Daicel Chiralcel OD-H, or a Daicel Chiralpak AD col umn. Starting materials $\mathbf{3}$ were employed with ee values $>99 \%$, except for (S)-3b (ee 92\%) and (R)-3d (ee 97\%). The ruthenium catalyst $\mathbf{A}^{27}$ was purchased from Fluka, the second generation catalyst B was prepared following a literature procedure. ${ }^{28}$

General Procedure for the Preparation of Allyloxy Ketones 4. To a solution of the corresponding $\alpha$-hydroxy ketone $3(2.0 \mathrm{mmol})$ and allyl bromide $(0.26 \mathrm{~mL}, 3.0 \mathrm{mmol})$ in ether $(30 \mathrm{~mL})$ was added silver oxide $(700 \mathrm{mg}, 3.0 \mathrm{mmol})$. The mixture was heated to reflux for $2 \mathrm{~h}$, and stirring was continued at ambient temperature in the dark for 2 days. All solids were removed by filtration through a small pad of Celite,

1249.

(25) Chen, X.; Hortelano, E. R.; Eliel, E. L.; Frye, S. V. J . Am. Chem. Soc. 1992, 114, 1778-1784.

(26) Reetz, M. T. Angew. Chem., Int. Ed. Engl. 1984, 23, 556-569.

(27) Schwab, P.; Grubbs, R. H.; Ziller, J . W. J . Am. Chem. Soc. 1996, $118,100-110$

(28) Scholl, M.; Ding, S.; Lee, C. W.; Grubbs, R. H. Org. Lett. 1999, 1, 953-956. 
the solvent was removed in vacuo, and the residue was purified by flash chromatography on silica using cyclohexane/MTBE mixtures as eluent.

(R)-2-Allyloxy-1,2-diphenylethanone (4a). Starting from (R)-benzoin (3a) (700 mg, $3.3 \mathrm{mmol}), 4 a(750 \mathrm{mg}, 90 \%)$ was obtained. Anal. Cal cd for $\mathrm{C}_{17} \mathrm{H}_{16} \mathrm{O}_{2}$ : C, 80.93; H, 6.39. F ound: C, 80.75; H, 6.25. MS (EI): m/z $253\left(\mathrm{M}^{+}+1,10\right), 105$ (100). IR (film): 1694 (s) cm ${ }^{-1}$. ${ }^{1} \mathrm{H}$ NMR $\left(400 \mathrm{MHz} \mathrm{CDCl}_{3}\right): \delta 7.94-$ $7.90(2 \mathrm{H}), 7.44-7.38(3 \mathrm{H}), 7.33-7.18(5 \mathrm{H}), 5.88$ (dddd, $1 \mathrm{H}, \mathrm{J}$ $=17.3,10.3,5.5,5.5), 5.60(\mathrm{~s}, 1 \mathrm{H}), 5.23(\mathrm{dddd}, 1 \mathrm{H}, \mathrm{J}=17.3$, $1.5,1.5,1.5), 5.15$ (dddd, $1 \mathrm{H}, \mathrm{J}=10.3,1.5,1.5,1.5), 4.04(\mathrm{dm}$, $2 \mathrm{H}, \mathrm{J}=5.5) .{ }^{13} \mathrm{C}$ NMR $\left(100 \mathrm{MHz} \mathrm{CDCl}_{3}\right): \delta 197.3(0), 136.2$ (0), $135.0(0), 134.0$ (1), $133.2(1), 129.1$ (1), 128.8 (1), 128.4 (1), $128.4(1), 127.5(1), 118.1(2), 83.9(1), 70.5(2) .[\alpha]^{22} \mathrm{D}+36.4$ (c $1.0, \mathrm{CH}_{2} \mathrm{Cl}_{2}$ ).

(S)- and (R)-2-Allyloxy-1-phenylpropan-1-one ((S)-4b and (R)-4b). Starting from either enantiomer of $\mathbf{3 b}$ (490 mg, $3.3 \mathbf{m m o l}$ ), the corresponding enantiomer of $\mathbf{4 b}$ (approxi mately $290 \mathrm{mg}, 47 \%$ ) and benzoic acid allyl ester were obtained as an inseparable mixture, which was used for subsequent transformations. The yield of $\mathbf{4} \mathbf{b}$ was estimated from the NMR spectrum of the mixture. NMR spectroscopic data for $\mathbf{4 b}$ (obtained from the mixture): ${ }^{1} \mathrm{H}$ NMR $\left(400 \mathrm{MHz} \mathrm{CDCl}_{3}\right): \delta$ 8.00-7.94 (2H), $7.45(\mathrm{~m}, 1 \mathrm{H}), 7.39-7.31(2 \mathrm{H}), 5.81$ (dddd, $1 \mathrm{H}$, $\mathrm{J}=17.3,10.5,5.8,5.5), 5.17$ (dddd, $1 \mathrm{H}, \mathrm{J}=17.3,1.5,1.5$, 1.5), $5.08(\mathrm{dm}, 1 \mathrm{H}, \mathrm{J}=10.3), 4.67(\mathrm{q}, 1 \mathrm{H}, \mathrm{J}=7.0), 4.00(\mathrm{ddm}$, $1 \mathrm{H}, \mathrm{J}=12.5,5.5), 3.85(\mathrm{ddm}, 1 \mathrm{H}, \mathrm{J}=12.5,5.8), 1.41(\mathrm{~d}, 3 \mathrm{H}$, $\mathrm{J}=7.0) .{ }^{13} \mathrm{C} \mathrm{NMR}\left(100 \mathrm{MHz} \mathrm{CDCl}_{3}\right): \delta 200.5(0), 134.1(0)$, $133.2(1), 128.6(1), 128.5(1), 128.5(1), 117.5(2), 77.9(1), 70.5$ (2), 18.7 (3)

(R)-2-Allyloxy-1,2-bis(3-methoxyphenyl)ethanone (4c). Starting from 3c (565 mg, $2.1 \mathrm{mmol}), 4$ c (640 mg, 99\%) was obtained.

(R)-2-Allyloxy-1,2-bis(2-chlorophenyl)ethanone (4d). Starting from 3d (420 mg, $1.5 \mathrm{mmol}$ ), 4d (361 mg, 75\%) was obtained after purification by column chromatography on silica.

(R)-2-Allyloxy-1,2-bis(4-bromophenyl)ethanone (4e). Starting from 3 e $(580 \mathrm{mg}, 1.5 \mathrm{mmol}), \mathbf{4 e}(450 \mathrm{mg}, 73 \%)$ was obtained after purification by column chromatography on silica.

General Procedure for the Preparation of Vinyl Carbinols 6. A solution of the corresponding ketone 4 (4.0 $\mathrm{mmol})$ in ether $(100 \mathrm{~mL})$ was cooled to $-78^{\circ} \mathrm{C}$. A solution of vinylmagnesium chloride in THF (1.7 M, $4.7 \mathrm{~mL}, 7.9 \mathrm{mmol})$ was added, and the mixture was stirred until the starting material was completely consumed, as indicated by TLC. The mixture was poured onto aqueous $\mathrm{NH}_{4} \mathrm{Cl}$ solution, the organic layer was separated, and the aqueous layer was extracted with MTBE. The combined organic extracts were dried with $\mathrm{MgSO}_{4}$, filtered, and evaporated. The residue was purified by flash chromatography on silica.

(1R,2S)-1-Allyloxy-1,2-diphenylbut-3-en-2-ol (6a). Starting from $4 \mathbf{a}(0.70 \mathrm{~g}, 2.8 \mathrm{mmol}), \mathbf{6 a}(0.77 \mathrm{~g}, 99 \%)$ was obtained. The enantiomeric excess of $\mathbf{6 a}$ was determined by HPLC analysis (Chiralpak AD, eluent: isohexane/2-propanol 95:5, flow $0.9 \mathrm{mLmin}^{-1}, 20^{\circ} \mathrm{C}$ ) to be $>99 \%$ after comparison with racemic 6a under identical conditions. Anal. Calcd for $\mathrm{C}_{19} \mathrm{H}_{20} \mathrm{O}_{2}$ : C, 81.40; $\mathrm{H}, 7.19$. Found: C, 81.30; $\mathrm{H}, 7.15$. MS (EI): $\mathrm{m} / \mathrm{z} 281$ (M+ $+1,<5), 147$ (70), 105 (100). IR (film): 3463 (br m), $1449(\mathrm{~m}), 925$ (m), 700 (s) cm-1. ${ }^{1} \mathrm{H}$ NMR $(400 \mathrm{MHz}$, $\left.\mathrm{CDCl}_{3}\right): \delta 7.24-7.20(2 \mathrm{H}), 7.17-7.07(6 \mathrm{H}), 7.03-6.98(2 \mathrm{H})$, $6.50(\mathrm{dd}, 1 \mathrm{H}, \mathrm{J}=17.5,10.8), 5.73$ (dddd, $1 \mathrm{H}, \mathrm{J}=17.0,10.8$, $5.3,5.0), 5.29(\mathrm{dd}, 1 \mathrm{H}, \mathrm{J}=17.3,1.3), 5.19(\mathrm{dd}, 1 \mathrm{H}, \mathrm{J}=10.8$, 1.3), $5.09(\mathrm{ddm}, 1 \mathrm{H}, \mathrm{J}=17.0,1.5), 5.05(\mathrm{ddm}, 1 \mathrm{H}, \mathrm{J}=10.8$, $1.5), 4.48(\mathrm{~s}, 1 \mathrm{H}), 3.88$ (dddd, $1 \mathrm{H}, \mathrm{J}=13.0,5.0,1.5,1.5), 3.65$ $(\mathrm{ddm}, 1 \mathrm{H}, \mathrm{J}=13.0,5.3), 2.63(\mathrm{br} \mathrm{s}, 1 \mathrm{H}) .{ }^{13} \mathrm{C}$ NMR $(100 \mathrm{MHz}$, $\left.\mathrm{CDCl}_{3}\right): \delta 142.7(0), 141.5(1), 136.6(0), 134.3(1), 128.7(1)$, 127.8 (1), 127.5 (1), 127.5 (1), 126.8 (1), 126.2 (1), 117.0 (2), 114.4 (2), 86.8 (1), 78.5 (0), 70.0 (2). [ $\alpha]^{25} \mathrm{D}-8.6$ (c 1.00, $\mathrm{CH}_{2^{-}}$ $\mathrm{Cl}_{2}$ ).
(3S,4R)- and (3R,4S)-4-Allyloxy-3-phenylpent-1-en-3-ol ((3S,4R)-6b and (3R,4S-6b)). Starting from (R)-4b (290 mg, $1.5 \mathrm{mmol}$ of a mixture with allyl benzoate), (3S,4R)-6b (220 $\mathrm{mg}, 67 \%$ ) was obtained. Analogously, from (S)-4b (270 mg, 1.4 $\mathrm{mmol}),(3 \mathrm{R}, 4 \mathrm{~S})-\mathbf{6 b}$ (190 mg, 62\%) was obtained. In both cases the products were contaminated with allylbenzoate from the preceding step. MS (EI): $\mathrm{m} / \mathrm{z} 191\left(\mathrm{M}^{+}-\mathrm{C}_{2} \mathrm{H}_{3}, 100\right), 105$ (85). $\left.{ }^{1} \mathrm{H} \mathrm{NMR}(400 \mathrm{MHz} \mathrm{CDCl})_{3}\right): \delta 7.44-7.40(2 \mathrm{H}), 7.33-7.28(2 \mathrm{H})$, $7.21(\mathrm{~m}, 1 \mathrm{H}), 6.34$ (dd, $1 \mathrm{H}, \mathrm{J}=17.3,10.5), 5.86$ (dddd, $1 \mathrm{H}, \mathrm{J}$ $=17.3,10.8,5.8,5.3), 5.35$ (dd, $1 \mathrm{H}$, J $=17.3,1.5), 5.25$ (dddd, $1 \mathrm{H}, \mathrm{J}=17.3,1.5,1.5,1.5), 5.18(\mathrm{dd}, 1 \mathrm{H}, \mathrm{J}=10.5,1.5), 5.14$ (dddd, $1 \mathrm{H}, \mathrm{J}=10.8,1.5,1.5,1.5), 4.09(\mathrm{ddm}, 1 \mathrm{H}, \mathrm{J}=12.8$, 5.3), $3.94(\mathrm{ddm}, 1 \mathrm{H}, \mathrm{J}=12.8,5.8), 3.77(\mathrm{q}, 1 \mathrm{H}, \mathrm{J}=6.0), 2.73$ (br s, $1 \mathrm{H}), 0.92(\mathrm{~d}, 3 \mathrm{H}, \mathrm{J}=6.0) .{ }^{13} \mathrm{C} \mathrm{NMR}\left(100 \mathrm{MHz} \mathrm{CDCl}_{3}\right)$ : $\delta 142.9$ (1), 134.9 (1), $128.7(0), 128.0$ (1), 126.7 (1), 125.4 (1), 116.8 (2), 113.5 (2), 79.8 (1), 78.8 (0), 70.7 (2), 13.7 (3).

(1R,2S)-1-Allyloxy-1,2-bis(3-methoxyphenyl)but-3-en2-ol (6c). Starting from 4c (598 mg, 1.9 mmol), 6c (513 mg, $79 \%$ ) was obtained.

(1R,2S)-1-Allyloxy-1,2-bis(2-chlorophenyl)but-3-en-2ol (6d). Starting from 4d (135 mg, $0.4 \mathrm{mmol}), 6 \mathbf{6}(130 \mathrm{mg}$, 85\%) was obtained.

(1R,2S)-1-Allyloxy-1,2-bis(4-bromophenyl)but-3-en-2ol (6e). Starting from 4 e (207 mg, 0.5 mmol ), $6 \mathbf{e e ~ ( 1 9 0 ~ m g , ~ 9 0 \% ) ~}$ was obtained.

General Procedure for the Preparation of Dihydropyrans 7. To a solution of the corresponding diene 6 (3.9 $\mathrm{mmol}$ ) in DCM (50 mL) was added the catalyst A (97 mg, 3 mol \%). The mixture was stirred until the starting material was completely converted, as indicated by TLC. The solvent was removed in vacuo, and the residue was purified by flash chromatography on silica.

(2R,3S)-2,3-Diphenyl-3,6-dihydro-2H-pyran-3-ol (7a). Starting from $\mathbf{6 a}(0.55 \mathrm{~g}, 1.9 \mathrm{mmol}), 7 \mathbf{a}(0.44 \mathrm{~g}, 90 \%)$ was obtained. Signal assignments in the $\mathrm{H}$ NMR spectrum are supported by $\mathrm{NOE}$ experiments. Anal. Calcd for $\mathrm{C}_{17} \mathrm{H}_{16} \mathrm{O}_{2}$ : C, 80.93; H, 6.39. Found: C, 80.75; H, 6.35. MS (EI): $\mathrm{m} / \mathrm{z} 251$ $\left(\mathrm{M}^{+}-1,<5\right), 146$ (100). IR (disk, KBr): $3510(\mathrm{~s}), 1495$ (m), $1447(\mathrm{~m}), 766$ (s), $698(\mathrm{~s}) \mathrm{cm}^{-1} .{ }^{1} \mathrm{H}$ NMR $\left(400 \mathrm{MHz}^{-} \mathrm{CDCl}_{3}\right): \delta$ 7.21-7.16 (3H, Ph), 7.13-7.04 (5H, Ph), 6.78-6.74 (2H, Ph), 6.09 (ddd, $1 \mathrm{H}, \mathrm{J}=10.0,3.5,1.5, \mathrm{H} 5), 6.02$ (ddd, $1 \mathrm{H}, \mathrm{J}=10.0$, $1.5,1.5, \mathrm{H} 4), 4.57$ (s, $1 \mathrm{H}, \mathrm{H} 2), 4.48$ (ddd, $1 \mathrm{H}$, J = 17.1, 3.5, $1.5, \mathrm{H} 6), 4.38$ (ddd, $1 \mathrm{H}, \mathrm{J}=17.1,1.5,1.5, \mathrm{H} 6), 2.33$ (br s, $1 \mathrm{H}$, $-\mathrm{OH}) .{ }^{13} \mathrm{C} \mathrm{NMR}\left(100 \mathrm{MHz} \mathrm{CDCl}_{3}\right): \delta 142.0(0), 136.2(0)$, 132.2 (1), $128.3(1), 127.8$ (1), 127.6 (1), 127.5 (1), 127.5 (1), $127.2(1), 126.1$ (1), 85.3 (1), $71.9(0), 66.8(2) .[\alpha]_{D}^{24} 17.1$ (c= $\left.0.69, \mathrm{CH}_{2} \mathrm{Cl}_{2}\right)$.

$(2 R, 3 S)$ - and (2S,3R)-2-Methyl-3-phenyl-3,6-dihydro2H-pyran-3-ol ((2R,3S)-7b and (2S,3R)-7b). Starting from (3S,4R)-6b (214 mg, $1.0 \mathrm{mmol}$ ), (2R,3S)-7b (160 mg, 86\%) was obtained. Analogously, from (3R,4S)-6b (140 mg, $0.6 \mathrm{mmol}$ ), (2S,3R )-7b (97 mg, 80\%) was obtained. Signal assignments in the H NMR spectrum are based on NOE experiments. Colorless crystals, $\mathrm{mp} 86^{\circ} \mathrm{C}$. Anal. Calcd for $\mathrm{C}_{12} \mathrm{H}_{14} \mathrm{O}_{2}$ : C, 75.76; $H, 7.42$. Found: $C, 75.56 ; H, 7.45$. MS (EI): $m / z 189\left(M^{+}-1\right.$, <5), 173 (100), 146 (80). IR (disk, KBr): 3463 (s), 1447 (m), 1117 (s), $994(\mathrm{~m}), 700(\mathrm{~s}) \mathrm{cm}^{-1}$. ${ }^{1} \mathrm{H}$ NMR $\left(500 \mathrm{MHz} \mathrm{CDCl}_{3}\right): \delta$ $7.40(\mathrm{dd}, 2 \mathrm{H}, \mathrm{J}=8.5,1.5, \mathrm{Ph}), 7.32(\mathrm{dd}, 2 \mathrm{H}, \mathrm{J}=8.5,7.0, \mathrm{Ph})$, $7.23(\mathrm{tt}, 1 \mathrm{H}, \mathrm{J}=7.0,1.5, \mathrm{Ph}), 6.01$ (ddd, $1 \mathrm{H}, \mathrm{J}=10.0,2.5$, 2.5, H4/H5), 5.93 (ddd, $1 \mathrm{H}, \mathrm{J}=10.0,1.5,1.5, \mathrm{H} 4 / \mathrm{H} 5), 4.32$ $(\mathrm{dm}, 1 \mathrm{H}, \mathrm{J}=17.1, \mathrm{H} 6), 4.26(\mathrm{dm}, 1 \mathrm{H}, \mathrm{J}=17.1, \mathrm{H} 6), 3.68(\mathrm{q}$, $1 \mathrm{H}, \mathrm{J}=6.3, \mathrm{H} 2), 2.58(\mathrm{br} \mathrm{s}, 1 \mathrm{H},-\mathrm{OH}), 1.04(\mathrm{~d}, 3 \mathrm{H}$, $\mathrm{J}=6.3$, $\left.-\mathrm{CH}_{3}\right) .{ }^{13} \mathrm{C}$ NMR (125 MHz, CDCl $): \delta 142.5(0), 132.4(1)$, 128.1 (1), $128.0(1), 127.0$ (1), 125.7 (1), 79.5 (1), $71.2(0), 66.2$ (2), 13.8 (3). (2R,3S)-(7b): $[\alpha]_{D} 27-79.5$ (c 1.50, $\mathrm{CH}_{2} \mathrm{Cl}_{2}$ ). (2S,3R)-(7b): $[\alpha]_{D}^{27}+81.0$ (c $1.02, \mathrm{CH}_{2} \mathrm{Cl}_{2}$ ).

(2R,3S)-2,3-Bis(3-methoxyphenyl)-3,6-dihydro-2H-pyran-3-ol (7c). Starting from 6c (217 mg, $0.6 \mathrm{mmol}), 7 c$ (180 mg, 90\%) was obtained.

(2R,3S)-2,3-Bis(2-chlorophenyl)-3,6-dihydro-2H-pyran3-ol (7d). Starting from 6d (102 mg, $0.3 \mathrm{mmol}), 7 d$ (70 mg, 
$75 \%)$ was obtained. A higher amount of ruthenium catalyst ( $25 \mathrm{mg}, 10 \mathrm{~mol} \%$ ) was required in this case.

(2R,3S)-2,3-Bis(4-bromophenyl)-3,6-dihydro-2H-pyran3-ol (7e). Starting from 6e (171 mg, $0.4 \mathrm{mmol}), 7 e$ (139 mg, $78 \%$ ) was obtained.

General Procedure for the Preparation of Diols 8. To a solution of the corresponding ketone $\mathbf{3}(2.3 \mathrm{mmol})$ in dry THF $(20 \mathrm{~mL})$ was added a solution of vinylmagnesium chloride (1 $\mathrm{M}$ solution in THF, $5.0 \mathrm{~mL}, 5.0 \mathrm{mmol}$ ) at $-78^{\circ} \mathrm{C}$. The mixture was stirred at this temperature until the starting material was fully consumed as indicated by TLC. Aqueous workup followed by flash chromatography on silica yielded the corresponding diol 8.

(1R,2S)-1,2-Bis(3-methoxyphenyl)-but-3-ene-1,2-diol (8c). Starting from 3c (270 mg, $1.0 \mathrm{mmol}), 8 \mathrm{c}(230 \mathrm{mg}, 76 \%)$ was obtained. The enantiomeric excess of $\mathbf{8 c}$ was determined by HPLC analysis (Daicel Chiralcel OD, eluent: heptane/2propanol $90: 10$, flow $1.0 \mathrm{~mL} \mathrm{~min}^{-1}, 20^{\circ} \mathrm{C}$ ) to be $>99 \%$ after comparison with racemic $\mathbf{8 c}$ under identical conditions. MS (EI, $70 \mathrm{eV}): \mathrm{m} / \mathrm{z} 283$ (3\%, M+ - OH), 165 (100). IR (film): 3474 (s), 1601 (s), 1585 (s), 1489 (s), 733 (s) cm ${ }^{-1}$. ${ }^{1} \mathrm{H}$ NMR (400 MHz, $\left.\mathrm{CDCl}_{3}\right): \delta 7.17(\mathrm{dd}, 1 \mathrm{H}, \mathrm{J}=8.0,8.0), 7.08(\mathrm{dd}, 1 \mathrm{H}, \mathrm{J}=8.0$, 8.0), $6.88(\mathrm{~d}, 1 \mathrm{H}, \mathrm{J}=7.7), 6.81(\mathrm{~m}, 1 \mathrm{H}, \mathrm{Ar}), 6.75-6.71(2 \mathrm{H})$, $6.68(\mathrm{~d}, 1 \mathrm{H}, \mathrm{J}=7.5), 6.58(\mathrm{~m}, 1 \mathrm{H}), 6.51(\mathrm{dd}, 1 \mathrm{H}, \mathrm{J}=17.2$, 10.7), 5.49 (dd, $1 \mathrm{H}, \mathrm{J}=17.2,1.0), 5.34(\mathrm{dd}, 1 \mathrm{H}, \mathrm{J}=10.7,1.0)$, $4.87(\mathrm{~d}, 1 \mathrm{H}, \mathrm{J}=3.0), 3.68(\mathrm{~s}, 3 \mathrm{H}), 3.63(\mathrm{~s}, 3 \mathrm{H}), 2.51(\mathrm{~s}, 1 \mathrm{H})$, $2.48(\mathrm{~d}, 1 \mathrm{H}, \mathrm{J}=3.0) .{ }^{13} \mathrm{C} \mathrm{NMR}\left(100 \mathrm{MHz} \mathrm{CDCl}_{3}\right): \delta 159.3(0)$, 158.9 (0), 143.7 (0), 140.7 (1), 139.8 (0), 128.8 (1), 128.5 (1), 120.1 (1), 118.5 (1), 115.4 (2), 113.9 (1), 113.0 (1), 112.8 (1), 111.9 (1), 79.7 (1), $79.2(0), 55.2(3), 55.1(3) .[\alpha]_{D}^{22}+18.7$ (c 1.30, $\mathrm{CH}_{2} \mathrm{Cl}_{2}$ ).

(2R,3S)-3-(3-Chlorophenyl)pent-4-ene-2,3-diol (8f). Starting from $3 f$ (420 mg, $2.3 \mathrm{mmol}$ ), 8f (396 mg, 81\%) was obtained. Anal. Calcd for $\mathrm{C}_{11} \mathrm{H}_{13} \mathrm{O}_{2} \mathrm{Cl}$ : C, 62.12; $\mathrm{H}, 6.16$. Found: $\mathrm{C}, 62.00$; $\mathrm{H}$, 5.95. MS (EI, $70 \mathrm{eV}): \mathrm{m} / \mathrm{z} 211$ (5\%, $\left.\mathrm{M}^{+}-1\right), 167$ (71), 139 (100). IR (film): 3442 (s), 1596 (s), 1572 (s), 786 (s), 697 (s)

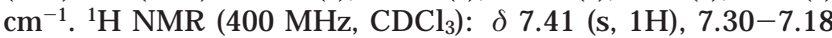
$(3 \mathrm{H}), 6.26(\mathrm{dd}, 1 \mathrm{H}, \mathrm{J}=17.1,10.5), 5.46(\mathrm{dd}, 1 \mathrm{H}, \mathrm{J}=17.1$, 1.0), 5.31 (dd, $1 \mathrm{H}, \mathrm{J}=10.5,1.0), 4.06(\mathrm{q}, 1 \mathrm{H}, \mathrm{J}=6.3), 2.67(\mathrm{~s}$, $1 \mathrm{H}), 1.97(\mathrm{~s}, 1 \mathrm{H}), 0.94(\mathrm{~d}, 3 \mathrm{H}, \mathrm{J}=6.3) .{ }^{13} \mathrm{C} N M R(100 \mathrm{MHz}$, $\left.\mathrm{CDCl}_{3}\right): \delta 144.5(0), 141.7(1), 134.4(0), 129.5(1), 127.2(1)$ 125.7 (1), $123.5(1), 115.2(2), 78.5(0), 72.5(1), 16.1(3) .[\alpha]_{D}{ }^{21}$ -36.0 (c $0.60, \mathrm{CH}_{2} \mathrm{Cl}_{2}$ ).

General Procedure for the Preparation of Acrylates 9. To a solution of the corresponding diol 8 ( $1.1 \mathrm{mmol})$ in dry DCM $(15 \mathrm{~mL})$ was added triethylamine $(0.50 \mathrm{~mL}, 3.3 \mathrm{mmol})$. The mixture was cooled to $0{ }^{\circ} \mathrm{C}$, and freshly distilled acryloyl chloride $(0.13 \mathrm{~mL}, 1.6 \mathrm{mmol})$ was added, followed by DMAP (11 $\mathrm{mg}, 0.1 \mathrm{mmol}$ ). After $30 \mathrm{~min}$ the starting material was completely consumed and the mixture was extracted with water. The organic layer was dried, filtered, and evaporated. The residue was purified by flash chromatography on silica to give the corresponding acrylate $\mathbf{9}$.

Acrylic Acid (1R,2S)-2-Hydroxy-1,2-bis(3-methoxyphenyl)but-3-enyl Ester (9c). Starting from 8c (130 mg, 0.4 $\mathrm{mmol})$, 9c (113 mg, 80\%) was obtained. Anal. Calcd for $\mathrm{C}_{21} \mathrm{H}_{22} \mathrm{O}_{5}$ : C, 71.17; $\mathrm{H}, 6.26$. Found: $\mathrm{C}, 71.20 ; \mathrm{H}, 6.25$. MS (EI, $70 \mathrm{eV}): \mathrm{m} / \mathrm{z} 283\left(\mathrm{M}^{+}-\mathrm{H}_{2} \mathrm{C}=\mathrm{CHCO}_{2} \mathrm{H}, 5 \%\right), 210$ (91), 181 (100). IR (film): 3489 (s), 2958 (s), 1724 (s), 1601 (s), 768 (s), 735 (s) $\mathrm{cm}^{-1} \cdot{ }^{1} \mathrm{H}$ NMR (500 MHz, $\left.\mathrm{CDCl}_{3}\right): \delta 7.18$ (dd, $1 \mathrm{H}, \mathrm{J}=$ 8.0, 8.0), $7.09(\mathrm{dd}, 1 \mathrm{H}, \mathrm{J}=8.0,8.0), 6.94(\mathrm{~d}, 1 \mathrm{H}, \mathrm{J}=8.0), 6.88$ $(\mathrm{m}, 1 \mathrm{H}), 6.76-6.69(3 \mathrm{H}), 6.60(\mathrm{~s}, 1 \mathrm{H}), 6.46(\mathrm{dd}, 1 \mathrm{H}, \mathrm{J}=17.2$, $11.0), 6.42(\mathrm{~d}, 1 \mathrm{H}, \mathrm{J}=17.5), 6.16(\mathrm{dd}, 1 \mathrm{H}, \mathrm{J}=17.5,10.5)$, $6.12(\mathrm{~s}, 1 \mathrm{H}), 5.85(\mathrm{~d}, 1 \mathrm{H}, \mathrm{J}=10.5), 5.40(\mathrm{~d}, 1 \mathrm{H}, \mathrm{J}=17.2), 5.26$ $(\mathrm{d}, 1 \mathrm{H}, \mathrm{J}=11.0), 3.70(\mathrm{~s}, 3 \mathrm{H}), 3.63(\mathrm{~s}, 3 \mathrm{H}), 2.34(\mathrm{~s}, 1 \mathrm{H}) .{ }^{13} \mathrm{C}$ NMR (125 MHz, CDCl $)$ : $\delta 164.8(0), 159.4(0), 158.8(0), 143.4$ (0), $140.4(1), 136.8(0), 131.5$ (2), 128.9 (1), 128.6 (1), 128.1 (1), 120.5 (1), 118.5 (1), 115.0 (2), 113.9 (1), 113.6 (1), 113.0 (1), $111.8(1), 80.0(1), 78.5(0), 55.2(3), 55.0(3) .[\alpha]_{D}^{21}+12.0$ (c $0.40, \mathrm{CH}_{2} \mathrm{Cl}_{2}$ ).
Acrylic Acid (1R,2S)-2-(3-Chlorophenyl)-2-hydroxy-1methylbut-3-enyl Ester (9f). Starting from 8 f (240 mg, 1,1 $\mathrm{mmol})$, 9f $(210 \mathrm{mg}, 72 \%)$ was obtained. Anal. Calcd for $\mathrm{C}_{14} \mathrm{H}_{15} \mathrm{O}_{3} \mathrm{Cl}$ : C, 63.04; $\mathrm{H}, 5.67$. Found: $\mathrm{C}, 63.05 ; \mathrm{H}, 5.45$. MS $(\mathrm{EI}, 70 \mathrm{eV}): \mathrm{m} / \mathrm{z} 194\left(5 \%, \mathrm{M}^{+}-\mathrm{H}_{2} \mathrm{C}=\mathrm{CHCO}_{2} \mathrm{H}\right), 167(40), 55$ (100). IR (film) 3491 (s), 1713 (s), 1635 (m), 1617 (m), 808 (m),

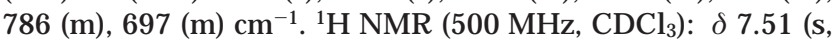
$1 \mathrm{H}), 7.34(\mathrm{~d}, 1 \mathrm{H}, \mathrm{J}=7.7), 7.29(\mathrm{~d}, 1 \mathrm{H}, \mathrm{J}=7.7), 7.25(\mathrm{dd}, 1 \mathrm{H}$, $\mathrm{J}=7.7,7.7), 6.41(\mathrm{~d}, 1 \mathrm{H}, \mathrm{J}=17.2), 6.22(\mathrm{dd}, 1 \mathrm{H}, \mathrm{J}=17.0$, $10.7), 6.11$ (dd, $1 \mathrm{H}, \mathrm{J}=17.2,10.5), 5.86(\mathrm{~d}, 1 \mathrm{H}, \mathrm{J}=10.5)$, $5.41(\mathrm{q}, 1 \mathrm{H}, \mathrm{J}=6.2), 5.36(\mathrm{~d}, 1 \mathrm{H}, \mathrm{J}=17.2), 5.21(\mathrm{~d}, 1 \mathrm{H}, \mathrm{J}=$ 10.7), $2.40(\mathrm{~s}, 1 \mathrm{H}), 1.08(\mathrm{~d}, 3 \mathrm{H}, \mathrm{J}=6.2) .{ }^{13} \mathrm{C} N M R(125 \mathrm{MHz}$, $\left.\mathrm{CDCl}_{3}\right): \delta 165.3(0), 144.0(0), 141.3(1), 134.4(0), 131.3(2)$, 129.6 (1), 128.2 (1), 127.4 (1), 125.8 (1), 123.6 (1), 114.6 (2), 78.1 (0), 74.9 (1), 14.0 (3). [ $\alpha]_{D}^{21}-24.5$ (c $0.40, \mathrm{CH}_{2} \mathrm{Cl}_{2}$ ).

General Procedure for the Ring Closing Metathesis of Acrylates 9. To a solution of the corresponding acrylate $\mathbf{9}$ $(0.6 \mathrm{mmol})$ in toluene $(30 \mathrm{~mL})$ was added ruthenium complex B $(19 \mathrm{mg}, 4 \mathrm{~mol} \%)$. The solution was heated to $70{ }^{\circ} \mathrm{C}$ until the starting material was completely consumed (approximately $1 \mathrm{~h}$ ). The solvent was evaporated and the residue was purified by flash chromatography on silica to give the corresponding lactone 10.

(5S,6R)-5-Hydroxy-5,6-bis(3-methoxyphenyl)-5,6-dihydropyran-2-one (10c). Starting from $9 c(130 \mathrm{mg}, 0.4 \mathrm{mmol})$, 10c (115 mg, 95\%) was obtained as colorless crystals, mp 120 ${ }^{\circ} \mathrm{C}$. Signal assignments in the H NMR spectrum are based on $\mathrm{H}, \mathrm{H}-\mathrm{COSY}$, and signal assignments in the C NMR spectrum are based on $\mathrm{C}-\mathrm{H}$-correlation spectroscopy. Anal. Calcd for $\mathrm{C}_{19} \mathrm{H}_{18} \mathrm{O}_{5}$ : C, 69.93; $\mathrm{H}, 5.56$. Found: $\mathrm{C}, 69.85 ; \mathrm{H}, 5.30$. MS (EI, $70 \mathrm{eV}$ ): m/z 326 (M+1 $1 \%$ ), 190 (100). IR (film): 3376 (s), 1721 (s), 1604 (s), 797 (s), 779 (s) $\mathrm{cm}^{-1}$. ${ }^{1 \mathrm{H}} \mathrm{NMR}\left(600 \mathrm{MHz}, \mathrm{CDCl}_{3}\right)$ : d $7.23\left(\mathrm{dd}, 1 \mathrm{H}, \mathrm{J}=8.0,8.0, \mathrm{C} 3-\mathrm{Ar}-\mathrm{H} 5^{\prime}\right), 7.06(\mathrm{dd}, 1 \mathrm{H}, \mathrm{J}=8.0$, 8.0, C2-Ar-H5'), $6.98(\mathrm{~d}, 1 \mathrm{H}, \mathrm{J}=9.9, \mathrm{H} 4), 6.83(\mathrm{dd}, 1 \mathrm{H}, \mathrm{J}=$ 8.4, 2.2, C3-Ar-H4'), 6.79 (dd, $1 \mathrm{H}, \mathrm{J}=8.1,2.2, \mathrm{C} 2-\mathrm{Ar}-\mathrm{H} 4^{\prime}$ ), $6.74\left(\mathrm{~d}, 1 \mathrm{H}, \mathrm{J}=7.7, \mathrm{C} 3-\mathrm{Ar}-\mathrm{H} 6^{\prime}\right), 6.66\left(\mathrm{~s}, 1 \mathrm{H}, \mathrm{C} 3-\mathrm{Ar}-\mathrm{H} 2^{\prime}\right), 6.52$ $\left(\mathrm{s}, 1 \mathrm{H}, \mathrm{C} 2-\mathrm{Ar}-\mathrm{H} 2^{\prime}\right), 6.48\left(\mathrm{~d}, 1 \mathrm{H}, \mathrm{J}=7.7, \mathrm{C} 2-\mathrm{Ar}-\mathrm{H}^{\prime}\right), 6.28(\mathrm{~d}$, $1 \mathrm{H}, \mathrm{J}=9.9, \mathrm{H} 5), 5.54(\mathrm{~s}, 1 \mathrm{H}, \mathrm{H} 2), 3.67\left(\mathrm{~s}, 3 \mathrm{H}, \mathrm{C} 3-\mathrm{Ar}-\mathrm{OCH}_{3}\right)$, $3.59\left(\mathrm{~s}, 3 \mathrm{H}, \mathrm{C} 2-\mathrm{Ar}-\mathrm{OCH}_{3}\right), 2.94(\mathrm{~s}, 1 \mathrm{H},-\mathrm{OH}) .{ }^{13} \mathrm{C} \mathrm{NMR}(150$ $\left.\mathrm{MHz}, \mathrm{CDCl}_{3}\right): \delta 163.8(0, \mathrm{C} 6), 159.6\left(0, \mathrm{C} 3-\mathrm{Ar}-\mathrm{C}-\mathrm{OCH}_{3}\right), 158.9$ (0, C2-Ar-C-OCH $\left.{ }_{3}\right), 149.4$ (1, C4), 142.0 (0, C3-Ar-C1'), 134.0 (0, C2-Ar-C1'), 129.5 (1, C3-Ar-C5'), 128.6 (1, C2-Ar-C5'), 121.6 (1, C5), 120.3 (1, C2-Ar-C6'), 118.1 (1, C3-Ar-C6'), 115.0 (1, C2-Ar-C4'), 113.9 (1, C3-Ar-C4'), 113.1, (1, C2-Ar-C2'), 111.8 (1, C3-Ar-C3'), 86.9 (1, C2), $70.9(0, \mathrm{C} 3), 55.3\left(3, \mathrm{C}^{-}-\mathrm{Ar}-\mathrm{OCH}_{3}\right)$, $55.1\left(3, \mathrm{C} 2-\mathrm{Ar}-\mathrm{OCH}_{3}\right) .[\alpha]_{D}{ }^{23}-75.9\left(\mathrm{c} 0.22, \mathrm{CH}_{2} \mathrm{Cl}_{2}\right)$.

(5S,6R)-5-(3-Chlorophenyl)-5-hydroxy-6-methyl-5,6-dihydropyran-2-one (10f). Starting from 9 f $(150 \mathrm{mg}, 0.6$ $\mathrm{mmol}$ ), $10 \mathrm{f}(121 \mathrm{mg}, 90 \%)$ was obtained as a colorless solid, $\mathrm{mp} 156^{\circ} \mathrm{C}$. Signal assignments in the H NMR spectrum are based on $\mathrm{H}, \mathrm{H}-\mathrm{COSY}$, and signal assignments in the $\mathrm{C} \mathrm{NMR}$ spectrum are based on $\mathrm{C}-\mathrm{H}$-correlation spectroscopy. Anal. Calcd for $\mathrm{C}_{12} \mathrm{H}_{11} \mathrm{O}_{3} \mathrm{Cl}$ : C, 60.39; $\mathrm{H}, 4.65$. Found: $\mathrm{C}, 60.30 ; \mathrm{H}$, 4.35. MS (EI, $70 \mathrm{eV}): \mathrm{m} / \mathrm{z} 194\left(\mathrm{M}^{+}-\mathrm{H}_{3} \mathrm{CCHO}, 95 \%\right), 131$ (100). IR (film): 3406 (s), 1719 (s), 1063 (s), 833 (m), 792 (m), 696 (m) $\mathrm{cm}^{-1}$. ${ }^{1} \mathrm{H}$ NMR $\left(600 \mathrm{MHz}, \mathrm{CDCl}_{3}\right): \delta 7.47(\mathrm{~s}, 1 \mathrm{H}, \mathrm{Ar}), 7.36-$ $7.25(3 \mathrm{H}, \mathrm{Ar}), 6.88(\mathrm{~d}, 1 \mathrm{H}, \mathrm{J}=9.5, \mathrm{H} 4), 6.20(\mathrm{~d}, 1 \mathrm{H}, \mathrm{J}=9.5$, $\mathrm{H} 5), 4.62(\mathrm{q}, 1 \mathrm{H}, \mathrm{J}=6.5, \mathrm{H} 2), 3.28(\mathrm{~s}, 1 \mathrm{H}, \mathrm{OH}), 1.25(\mathrm{~d}, 3 \mathrm{H}, \mathrm{J}$ $\left.=6.5,-\mathrm{CH}_{3}\right) .{ }^{13} \mathrm{C}$ NMR $\left(125 \mathrm{MHz}, \mathrm{CDCl}_{3}\right): \delta 163.9(0, \mathrm{C} 6)$, 149.4 (1, C4), 142.6 (0, ipso-C, Ar), 134.7 (0, C-Cl, Ar), 129.9 (1, Ar), 128.4 (1, Ar), 126.0 (1, Ar), 123.8 (1, Ar), 121.8 (1, C5), 82.1 (1, C2), $69.9(0, \mathrm{C} 3), 13.4\left(3,-\mathrm{CH}_{3}\right)$. $[\alpha]_{\mathrm{D}}^{21}-73.5$ (c 0.31, $\mathrm{CH}_{2} \mathrm{Cl}_{2}$ ).

Acknowledgment. This work was generously supported by the Deutsche F orschungsgemeinschaft (P.D., M.M.: SFB 380) and the Fonds der Chemischen Indus- 
trie. Financial support by the Department of Chemistry, Universität Dortmund, is also gratefully acknowledged. B.S. thanks Dr. B. Plietker for HPLC measurements and Dr. B. Costisella for conducting nonroutine NMR experiments.
Supporting Information Available: Copies of ${ }^{1} \mathrm{H}$ and ${ }^{13} \mathrm{C}$ NMR spectra of $\mathbf{4 c}-\mathbf{e}, \mathbf{6 d}, \mathbf{e}, \mathbf{7 c}-\mathbf{e}$, and $\mathbf{8 c}$; analytical data for compounds $\mathbf{4 c}-\mathbf{e}, \mathbf{6 c}-\mathbf{e}$, and $\mathbf{7 c}-\mathbf{e}$. This material is available free of charge via the Internet at http://pubs.acs.org.

J 00264729 